\title{
Konsep Pengendalian Mutu pada Pembuatan Permen Jelly Nenas (Ananas Comosus L.)
}

\author{
Nur Amaliah ${ }^{1 *}$, Farida $^{2}$ \\ ${ }^{1,2}$ Politeknik Negeri Balikpapan \\ *nur.amaliah@poltekba.ac.id
}

\begin{abstract}
In the process of processing jelly candy of pineapple requires supervision related to food safety and quality assurance. food quality control is one way to get safe and healthy products according to panelists' requests. The aim is to determine the effect of gelling agent on jelly pineapple candy products, to determine the process of making jelly pineapple candy by applying the concept of quality control, and knowing the level of product preference and quality from organoleptic testing. The method used is quantitative qualitative descriptive where the results of the analysis obtained will be described. The results obtained are gelatin is the best gelling agent in making pineapple jelly candy products. Control control point in the manufacture of jelly pineapple candy is the selection of raw materials, standard weighing material, processing temperature, and drying. The results of chemical analysis of pineapple jelly candy for water content of $15.30 \%$, ash content $0.89 \%$, protein content $1.49 \%$, carbohydrate $82.03 \%$, crude fat $0.79 \%$, fiber $1.25 \%$, and vit C $13.10 \mathrm{mg} / 100 \mathrm{~g}$ sample. Microbiological analysis, there are $1.3 \times 10-3$ colonies $/ \mathrm{g}$ and E.coli bacteria analysis is $<3$ APM / g. The results of organoleptic analysis from the level of preference of panelists in pineapple candy are rather like the color, aroma, taste, while liking the texture. The hedonic quality test for pineapple candy is rather not bright yellow in color, chewy and elastic in texture, slightly pineapple-flavored, and sweet. The results of chemical and microbiological analysis are in accordance with SNI for jelly candy, while organoleptic tests require modification to get the best product according to consumer demand.
\end{abstract}

Keywords: gelatin, pineapple, candy

\begin{abstract}
Abstrak
Dalam proses pengolahan permen jelly nenas membutuhkan pengawasan terkait keamanan pangan dan jaminan mutu. pengendalian mutu pangan merupakan salah satu cara untuk mendapatkan produk yang aman dan sehat sesuai dengan permintaan panelis. Tujuannya yaitu untuk mengetahui pengaruh gelling agent terhadap produk permen jelly nenas, untuk mengetahui proses pembuatan permen jelly nenas dengan menerapkan konsep pengendalian mutu, dan pengetahui tingkat kesukaan dan mutu produk dari pengujian organoleptik. Metode yang digunakan yaitu deskriptif kualitatif kuantitatif dimana hasil analisa yang diperoleh akan dideskripsikan. Hasil yang diperoleh yaitu gelatin adalah gelling agent terbaik dalam pembuatan produk permen jelly nenas. Titik kontrol kendali dalam pembuatan permen jelly nenas yaitu pemilihan bahan baku, standar menimbang bahan, suhu pengolahan, dan pengeringan. Hasil analisa kimia permen jelly nenas untuk kadar air sebesar $15,30 \%$, kadar abu $0,89 \%$, kadar protein $1,49 \%$, karbohidrat $82,03 \%$, lemak kasar $0,79 \%$, serat $1,25 \%$, dan vit C $13,10 \mathrm{mg} / 100 \mathrm{~g}$ sampel. Analisa mikrobiologi yaitu terdapat $1,3 \times 10^{-3} \mathrm{koloni} / \mathrm{g}$ dan analisa bakteri E.coli adalah <3 APM/g. Hasil analisa organoleptik dari tingkat kesukaan panelis pada permen nenas yaitu agak suka pada warna, aroma, rasa, sedangkan suka pada tekstur. Uji mutu hedonik permen nenas yaitu agak tidak kuning cerah pada warna, kenyal dan elastis pada tekstur, agak beraroma nenas, dan rasa manis. Hasil analisa kimia dan mikrobiologi sudah sesuai dengan SNI permen jelly, sedangkan uji organoleptik membutuhkan modifikasi untuk mendapatkan produk terbaik sesuai permintaan konsumen.
\end{abstract}

Kata kunci: gelatin, nenas, permen 


\section{Pendahuluan}

\subsection{Latar Belakang}

Kalimantan Timur khususnya Kabupaten Kutai Kartanegara mempunyai luas wilayah 27.263,10 km2 atau 12,89 \% dari wilayah Kalimantan Timur. Kabupaten Kutai Kartanegara merupakan wilayah yang berpotensi untuk pengembangan tanaman buah-buahan. Adapun buahbuahan yang diproduksi diantaranya adalah pisang, durian, papaya, nenas dan buah naga. Ratarata produksi tertinggi selama 5 (lima) tahun ditempati oleh tanaman pisang dengan jumlah produksi 42.997,20 ton, disusul nenas $16.344,40$ ton, durian $12.558,80$ ton dan papaya 8.228,60 ton. Menurut Dinas Pertanian Tanaman Pangan dan Hortikultura (2013), Perkembangan tanaman pangan lainnya adalah tanaman sayuran. Kecamatan samboja dan kota tenggarong merupakan salah satu tempat budidaya nenas yang ada di Kabupaten Kutai Kartanegara. Jenis nenas yang dibudidayakan adalah nenas srikaya dan nenas madu.

Banyaknya hasil panen buah nenas tersebut, tentunya ada permasalan yang dialami oleh petani ataupun penjual buah nenas. Omset penjualan buah nenas di Balikpapan (tempat pemasaran buah nenas) pada tahun 2016 mengalami penurunan dan berbeda dengan tahun-tahun sebelumnya. Hal ini karena faktor ekonomi lesuh dan kebutuhan masyarakat yang banyak sehingga pendapatan pedangan buah nenas berkurang. Omset yang didapat dari hasil penjualan nenas setiap bulannya Rp 8 juta - Rp. 9 juta berbeda dari tahun sebelumnya yang dapat mencapai Rp. 12 juta. Hal tersebut membuka peluang dalam pemanfaatan buah nenas untuk diinovasikan menjadi produk yang bernilai dan meningkatkan pendapatan. Dengan mengolahnya menjadi berbagai macam produk olahan maka akan meningkatkan daya simpan dari resiko busuk dan jangkauan pemasarannya lebih luas. Disamping itu juga dapat meningkatkan nilai tambah dan pendapatan petani. Teknologi pengolahan yang di introduksikan tidak harus rumit tetapi dapat yang sederhana dan mudah diterapkan serta digunakan oleh petani (Sudarwati, 2006).

Nenas merupakan tanaman buah berupa semak yang memiliki nama ilmiah Ananas comosus. Buah nenas sangat populer karena memiliki aroma khas dan tajam dengan rasa asam bercampur dengan manis. Selain itu nenas merupakan buah yang mudah rusak, sehingga memerlukan alternatif dalam mempertahankan kondisi komoditi nenas dengan melakukan proses pengolahan buah nenas menjadi produk yang layak untuk dikonsumsi. Nenas memiliki kadar pektin yang rendah namun tingkat keasaman yang cukup untuk pembentukan gel pada permen jelly (Albrecht, 2010).Karena kadar pektin yang rendah, maka perlu ditambahkan bahan pembentuk gel untuk dapat membuat permen jelly dari buah nenas. Permen jelly merupakan permen lunak yang terbuat dari sari buah dan ditambah pemanis serta pengenyal sehingga mempunyai sifat yang elastis. Dengan adanya pengolahan buah nenas menjadi permen jelly diharapkan dapat memberikan nilai tambah secara ekonomi dari buah nenas tersebut. oleh karena itu, proses pembuatan permen jelly diharapkan mampu menghasilkan permen jelly nenas sesuai selera panelis dan memenuhi standar SNI.

Dalam proses pengolahan permen jelly nenas membutuhkan pengawasan terkait keamanan pangan dan jaminan mutu. pengendalian mutu pangan merupakan salah satu cara untuk mendapatkan produk yang aman dan sehat sesuai dengan permintaan panelis. Dengan mengendalikan mutu pangan diharapkan dapat mengurangi kerusakan yang disebabkan oleh bahan baku, proses, dan juga kondisi dilapangan. Oleh karena itu, dalam penelitian ini akan melakukan pengendalian mutu produk permen jelly melalui perbaikan input, proses, dan output dengan melihat sebab akibat dari masalah yang akan terjadi.

\subsection{Rumusan Masalah}

Berdasarkan latar belakang di atas, rumusan masalah yang diteliti dalam penelitian ini adalah

1. Bagaimana pengaruh gelling agent terhadap produk permen jelly nenas? 
2. Bagaimana proses pembuatan permen jelly nenas sesuai standar?

3. Bagaimana penerapan pengendalian mutu pada proses pengolahan permen jelly nenas?

\section{Metodologi}

\subsection{Road Map Penelitian}

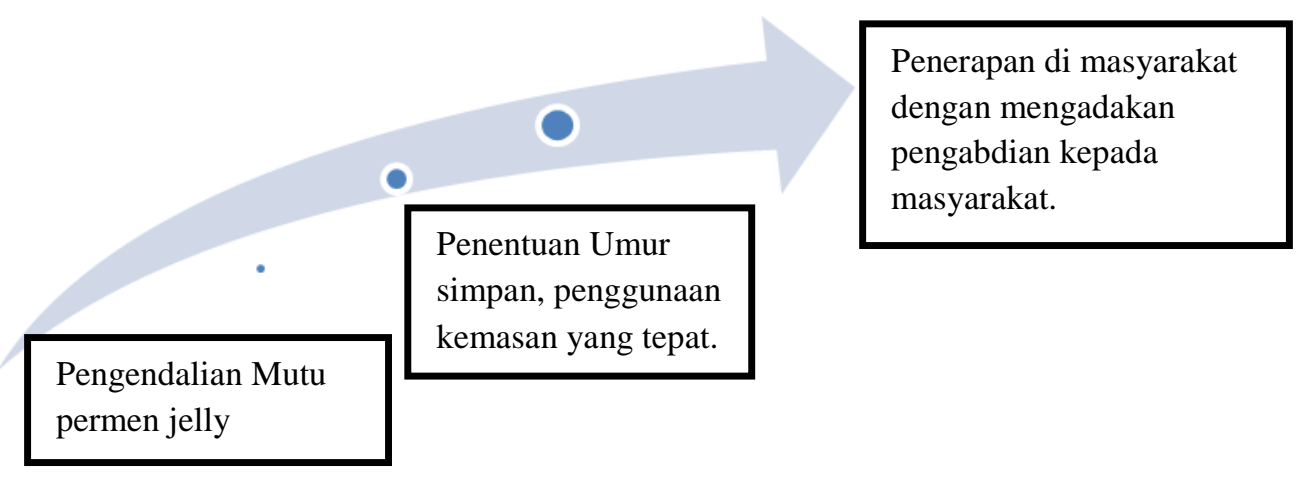

Gambar 1. Roadmap Penelitian

\subsection{Tahapan Penelitian}

\section{a. Penelitian Pendahuluan}

Pada penelitian pendahuluan, akan dilakukan uji coba resep standar dengan melakukan perbandingan penggunaan gelling agent. Gelling agent yang digunakan antara lain agar-agar, pektin, dan gelatin. Perlakuan yang terbaik dari gelling agent akan digunakan dalam proses pembuatan permen jelly. Pengendalian mutu pangan akan diamati dengan menggunakan pendekatan kualitatif yaitu menggunakan flow chart dan diagram sebab akibat (Fishbone) untuk mengetahui kerusakan yang terjadi pada permen jelly nenas.

\section{b. Penelitian Lanjutan}

Penelitian lanjutan dalam penelitian ini yaitu melakukan analisa nutrisi dengan menggunakan metoda analisis kimia untuk mengidentifikasi kandungan nutrisi berupa protein, karbohidrat, lemak, kadar air, kadar abu dan serat dalam permen jelly nenas. uji mikrobiologi berupa total mikroba dan analisa E.Coli.

\section{Hasil dan Pembahasan}

\subsection{Penentuan gelling agent dengan mengamati fisik dari permen Jelly}

Permen jelly membutuhkan gelling agent untuk membentuk gel yang akan menjadikan permen menjadi elastis. Dalam penelitian ini dilakukan uji coba dengan menggunakan gelling agent untuk mengetahui pengaruh organoleptik pada permen jelly meliputi warna, tekstur, aroma, dan rasa. Adapun hasil yang diperoleh dalam penentuan gelling agent dapat dilihat pada tabel 4.1 di bawah ini :

Tabel.2.1. Penentuan Gelling Agent Pada Permen Jelly Nenas

\begin{tabular}{cccc}
\hline Pengamatan & \multicolumn{3}{c}{ Perlakuan } \\
\cline { 2 - 4 } Fisik & Agar-agar & Pektin & Gelatin \\
\hline Warna & Kuning cerah & Kuning pucat & Kuning gelap \\
\hline Tekstur & Kurang elastis & Agak elastis & Elastis \\
\hline Aroma & Agak khas nenas & Agak khas nenas & Khas nenas \\
\hline Rasa & Manis & Manis & Manis \\
\hline \multicolumn{2}{c}{ Sumber : Data Primer, 2018 } \\
\end{tabular}

\subsection{Analisa Pengawasan Mutu Pangan}

Analisa yang dilakukan pada pengawasan mutu pangan dengan menggunakan diagram tulang ikan (fishbone). Analisa dilakukan untuk mengendalikan kualitas produk dengan melihat 
$s e b a b$ akibat yang akan terjadi pada permen jelly nenas yang tidak kenyal/elastis. Pengendalian mutu pada permen jelly nenas terbagi menjadi tiga tahapan yaitu pengendalian mutu bahan baku, pengendalian mutu dalam proses, dan pengendalian mutu produk jadi.

1. Pengendalian mutu bahan baku

Evaluasi mutu bahan baku bertujuan untuk menganalisa bahan baku yang digunakan dalam produksi permen jelly nenas sesuai dengan Standar Nasional Indonesia dari tiap bahan yang digunakan. Evaluasi dilakukan dengan menggunakan uji organoleptik yaitu pengujian sifat fisik bahan pangan seperti warna, tekstur, aroma, dan rasa pada setiap bahan baku dan bahan penunjang. Adapun bahan baku yang digunakan sebagai berikut :

Tabel 2.2. Analisa Bahan Baku

\begin{tabular}{|c|c|c|c|}
\hline No & $\begin{array}{c}\text { Bahan } \\
\text { Baku }\end{array}$ & Hasil Uji & SNI \\
\hline \multirow[t]{7}{*}{1.} & Nenas & Bentuk nenas utuh, tingkat kematangan & Persyaratan (SNI-3166-2009) \\
\hline & & $80 \%$, tidak keriput dan tidak busuk. & Bentuk nenas tidak cacat, tidak \\
\hline & & Warna nenas kulit orange dan warna & keriput, tidak busuk atau rusak. \\
\hline & & daging buah kuning. & Normal \\
\hline & & Tekstur padat dan berair. & Normal \\
\hline & & Khas nenas & Khas nenas \\
\hline & & Khas nenas & Khas nanas \\
\hline \multirow[t]{6}{*}{2} & Gelatin & Serbuk & $\begin{array}{llll}\text { Persyaratan } & \text { (SNI } & \text { No. } & \mathbf{0 6}-3735\end{array}$ \\
\hline & & Kuning kecoklatan & Tahun1995 dan British Standard: \\
\hline & & Kasar & 757 Tahun 1975) \\
\hline & & Tidak beraroma & Gelatin tidak berwarna sampai \\
\hline & & & kekuningan atau kuning pucat. \\
\hline & & & Bau dan rasa normal. \\
\hline \multirow[t]{5}{*}{3} & Sukrosa & Berkristal putih bersih. & Persyaratan (SNI 01-3140-2001) \\
\hline & & Warna putih & Keadaan : \\
\hline & & Kasar & Bau normal \\
\hline & & Tak beraroma & Rasa normal \\
\hline & & Manis & \\
\hline \multirow[t]{6}{*}{4} & Asam Sitrat & Kristal bening & Persyaratan (SNI 06-0079-1987) \\
\hline & & bening & Keadaan : \\
\hline & & kasar & Pada suhu ruang berbentuk Kristal \\
\hline & & tidak ada aroma & putih \\
\hline & & asam & Bau normal \\
\hline & & & Rasa normal \\
\hline
\end{tabular}

Sumber : Sumber : Data Primer, 2018

\section{Pengendalian Mutu Proses}

Pendekatan proses produksi dalam pengendalian mutu merupakan pengendalian mutu yang lebih menitikberatkan pada pengendalian mutu selama proses produksi yang sebaik-baiknya agar diperoleh produk akhir dengan mutu yang sesuai dengan standar. Proses produksi pada pembuatan permen terbagi menjadi dua bagian yaitu proses pembuatan sari buah nenas dan proses pembuatan permen jelly nenas. Adapun proses produksi dapat dilihat pada gambar 4 mengenai diagram alir proses pembuatan permen jelly nenas. 
Tabel 2.3. Pengendalian Mutu Proses

\begin{tabular}{|c|c|c|c|c|}
\hline No & $\begin{array}{l}\text { Tahap proses } \\
\text { produksi }\end{array}$ & Parameter & Batas Kritis & Hasil analisa \\
\hline \multicolumn{5}{|c|}{ Pengolahan sari buah nenas } \\
\hline 1 & Pengupasan & $\begin{array}{l}\text { Kebersihan alat, } \\
\text { kulit dan biji } \\
\text { mata nenas }\end{array}$ & $\begin{array}{l}\text { Pisau bebas karat, } \\
\text { Tidak terdapat kulit dan biji } \\
\text { mata buah nenas }\end{array}$ & $\begin{array}{l}\text { Tekstur kulit yang keras } \\
\text { dan biji mata pada kulit } \\
\text { dihilangkan untuk } \\
\text { mencegah gatal }\end{array}$ \\
\hline 2 & Pencucian & $\begin{array}{l}\text { Menggunakan air } \\
\text { mengalir }\end{array}$ & $\begin{array}{l}\text { Air bersih tidak } \\
\text { mengandung senyawa } \\
\text { berbahaya. }\end{array}$ & $\begin{array}{l}\text { Menggunakan air bersih } \\
\text { dan mengalir. }\end{array}$ \\
\hline 3 & $\begin{array}{l}\text { Pemarutan daging } \\
\text { buah }\end{array}$ & $\begin{array}{l}\text { Kebersihan alat, } \\
\text { penghancuran } \\
\text { daging buah } \\
\text { nenas }\end{array}$ & $\begin{array}{l}\text { Parutan tidak berkarat, hasil } \\
\text { parutan tidak halus. }\end{array}$ & $\begin{array}{l}\text { Hasil parutan tidak halus } \\
\text { agar ampas halus tidak } \\
\text { tercampur pada sari buah } \\
\text { nenas. }\end{array}$ \\
\hline 4 & Penyaringan & $\begin{array}{l}\text { Kebersihan } \\
\text { saringan, dan } \\
\text { ukuran saringan }\end{array}$ & Tidak terdapat ampas & $\begin{array}{l}\text { Penyarinagn dilakukan } \\
\text { sebanyak } 2 \text { kali } \\
\text { penyaringan menggunakan } \\
\text { saringan } 80 \text { mesh }\end{array}$ \\
\hline \multicolumn{5}{|c|}{ Pembuatan permen jelly } \\
\hline 5 & $\begin{array}{l}\text { Penimbangan } \\
\text { bahan }\end{array}$ & $\begin{array}{l}\text { Kalibrasi } \\
\text { timbangan }\end{array}$ & Sesuai dengan formula & $\begin{array}{l}\text { Keakuratan penimbangan } \\
\text { sesuai dengan formula } \\
\text { permen jelly nenas }\end{array}$ \\
\hline 6 & Pemanasan & $\begin{array}{l}\text { Pengecekan } \\
\text { thermometer, suhu }\end{array}$ & $\begin{array}{l}\text { Suhu thermometer harus } \\
\text { dicek sebelum penggunaan, } \\
\text { suhu pemanasan berkisar } \\
\text { antara } 80-90^{\circ} \mathrm{C}\end{array}$ & Kontrol suhu pemanasan \\
\hline 7 & Pencampuran & $\begin{array}{l}\text { Kebersihan alat } \\
\text { dan homogenitas }\end{array}$ & $\begin{array}{l}\text { Bebas dari kotoran, } \\
\text { Pengadukan tanpa henti }\end{array}$ & $\begin{array}{l}\text { Pencucian pengaduk } \\
\text { sebelum dan sesudah } \\
\text { digunakan, Pengadukan } \\
\text { dilakukan terus hingga } \\
\text { permen matang }\end{array}$ \\
\hline 8 & Pencetakan & $\begin{array}{l}\text { Kebersihan } \\
\text { cetakan, bentuk, } \\
\text { dan ukuran } \\
\text { permen jelly }\end{array}$ & $\begin{array}{l}\text { Bebas dari kotoran, bentuk } \\
\text { sesuai cetakan, dan ukuran } \\
\text { permen yang seragam }\end{array}$ & $\begin{array}{l}\text { Pencucian cetakan } \\
\text { sebelum dan sesudah } \\
\text { digunakan }\end{array}$ \\
\hline 9 & Pendinginan & $\begin{array}{l}\text { Kebersihan } \\
\text { tempat dan suhu } \\
\text { penyimpanan }\end{array}$ & $\begin{array}{l}\text { Tempat bebas dari } \\
\text { kontaminasi, suhu antara } 22- \\
28{ }^{\circ} \mathrm{C}\end{array}$ & $\begin{array}{l}\text { Sanitasi alat dan } \\
\text { lingkungan dan pekerja } \\
\text { yang sempurna }\end{array}$ \\
\hline
\end{tabular}

3. Pengendalian mutu hasil akhir

Pengendalian mutu produk akhir perlu dilakukan sebagai upaya untuk mempertahankan mutu produk agar tidak mengalami penurunan mutu selama proses penyimpanan dan distribusi. Hal-hal yang harus dilakukan dalam penelitian ini yaitu pengawasan atau pemeriksaan mutu permen jelly nenas dengan menganalisa pemilihan bahan baku dan proses produksi. Dengan menyesuaikan dengan Standar Nasional Indonesia (SNI). Dapat dilihat analisa kimia dari permen jelly nenas, hasil yang diperoleh sudah sesuai dengan SNI. Adapun hasil analisa kimia permen jelly dapat dilihat pada tabel 4.7 dibawah ini : 
Tabel 2.4. Hasil Analisa Kimia Permen Jelly Nenas

\begin{tabular}{clc}
\hline No & Parameter Pengujian & Hasil Analisa \\
\hline 1 & Kadar air $(\%)$ & 15,3045 \\
\hline 2 & Kadar abu (\%) & 0,8952 \\
\hline 3 & Protein $(\%)$ & 1,4884 \\
\hline 4 & Lemak kasar (\%) & 0,7879 \\
\hline 5 & Karbohidrat (\%) & 82,024 \\
\hline 6 & Serat $(\%)$ & 1,2465 \\
\hline 7 & Vit C $(\mathrm{mg} / 100 \mathrm{~g})$ & 13,1 \\
\hline & \multicolumn{2}{c}{ Sumber : Data Primer, 2018}
\end{tabular}

Pada hasil analisa mikrobiologi, dilakukan pengujian analisa total mikroba dan analisa bakteri E. coli. Adapun hasil analisa dapat dilihat pada tabel dibawah ini :

Tabel 2.5. Hasil Analisa Angka Lempeng Total

\begin{tabular}{llll}
\hline No & Sampel Pengenceran & Rata-rata Koloni & Hasil Perhitungan ALT \\
\hline 1 & $10^{-3}$ & 61,5 & $1,3 \times 10^{-3}$ Koloni/g \\
& $10^{-3}$ & 5 & \\
& & & \\
\hline
\end{tabular}

Sumber : Data Primer, 2018

Hasil yang diperoleh dari tabel diatas menunjukkan terdapatnya mikroba pada pengenceran ketiga sebanyak $1,3 \times 10^{-3}$ koloni/gram. Hal ini masih dalam batas aman dimana menurut SNI 3547.2-2008 [10] menyatakan angka ambang total max $5 \times 10^{-4} \mathrm{koloni} / \mathrm{g}$. Terdapatnya koloni disebabkan penanganan hasil akhir produk. Karyawan yang merupakan sumber kontaminan harus dalam keadaan bersih dan menggunakan perlengkapan seperti sarung tangan, masker, penutup kepala saat mengeluarkan permen dari cetakan. Selain karyawan, tempat atau wadah cetakan harus bersih. Dan lingkungan tempat pengeringan permen harus terjaga sebersih mungkin.

Tabel 2.6. Hasil Analisa Bakteri E.coli

\begin{tabular}{|l|l|l|l|}
\hline No & \multicolumn{1}{|c|}{ Sampel Pengenceran } & Pembentukan gas & Hasil Tabel MPN Seri 3 Tabung \\
\hline 1 & $10^{-1}$ & 0 & $<3$ APM/g \\
& $10-^{2}$ & 0 & \\
& $10^{-3}$ & 0 & \\
\hline
\end{tabular}

Sumber : Data Primer, 2018

Hasil yang diperoleh dari tabel diatas menunjukkan bahwa bakteri E. coli tidak ditemukan pada produk permen jelly. Hal ini disebabkan pemilihan bahan baku yang baik serta proses pengolahan yang tepat dan lingkungan kerja sesuai dengan penerapan hygiene sanitasi sehingga tidak ditemukan E. coli.

4. Analisa Sebab Akibat Menggunakan Diagram Tulang Ikan (fishbone diagram)

Kontrol atau pengawasan produk harus terus dilakukan. Dari analisa pengendalian bahan baku, pengendalian proses, dan pengendalian produk akhir akan ada cacat produk permen jelly yang dihasilkan. oleh sebab itu harus dilakukan pengawasan dengan melihat sebab akibat dari cacat dari permen jelly nenas. Adapun cacat yang diperoleh yaitu tekstur permen jelly nenas yang tidak standar atau kekenyalan yang selalu berubah-ubah. Adapun hubungan faktor kecacatan dengan masalah yang terjadi yaitu standar tekstur permen jelly nenas yang berubah-ubah dapat dilihat pada diagram tulang ikan (fishbone diagram) di bawah ini : 


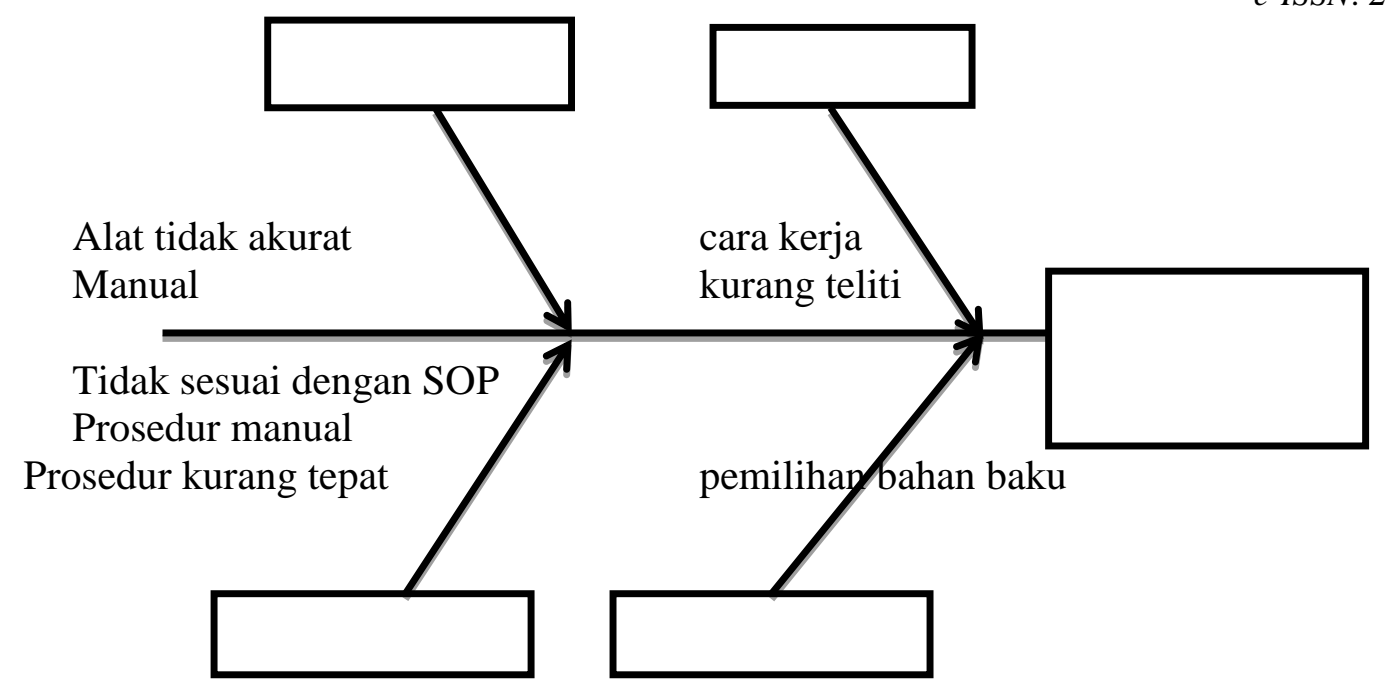

\section{Kesimpulan}

Gambar 3.2. Fishbone Permen Jelly Nenas

Pembentuk gel (gelling agent) yang terbaik dalam pembuatan permen jelly nenas yaitu dengan menggunakan gelatin. Prosedur pembuatan dengan pemilihan bahan baku, menimbang bahan, pemasakan hingga suhu $90{ }^{\circ} \mathrm{C}$, dan proses pencetakan. Penerapan pengendalian mutu dengan menggunakan analisa pengendalian bahan baku, pengendalian proses, dan pengendalian produk akhir. Hasil analisa organoleptik dari tingkat kesukaan panelis pada permen nenas yaitu agak suka pada warna, aroma, rasa, sedangkan suka pada tekstur. uji mutu hedonik permen nenas yaitu agak tidak kuning cerah pada warna, kenyal dan elastis pada tekstur, agak beraroma nenas, dan rasa manis. Hasil analisa kimia dan mikrobiologi sudah sesuai dengan sni permen jelly, sedangkan uji organoleptik membutuhkan modifikasi untuk mendapatkan produk terbaik sesuai permintaan konsumen.

\section{Saran}

Dalam penelitian selanjutnya dilakukan modifikasi formula agar warna, aroma, dan rasa lebih disukai oleh konsumen. Dan dilakukan pemilihan jenis kemasan dan pengukuran masa simpan produk agar mengetahui lama penyimpanan permen jelly nenas.

\section{Ucapan Terimakasih}

Terimakasih kami sampaikan kepada Pusat Penelitian dan Pengabdian kepada Masyarakat Politeknik Negeri Balikpapan atas dukungan dana yang diberikan sehingga penelitian ini bisa terlaksana.

\section{Daftar Pustaka}

Albrecht, J.A. (2010). Let's Preserve : Jams, Jellies, and Preserves. University of NebraskaLincoln and United States Department of Agriculture. United States of America

Badan Standarisasi Nasional. (2009). Standar Mutu Buah Nenas, SNI SNI 3166-2009.Dewan Standarisasi Nasional, Jakarta

Badan Standarisasi Nasional. (1995). Standar Mutu Gelatin, SNI No. 06-3735 Tahun 1995 dan British Standard: 757 Tahun 1975.Dewan Standarisasi Nasional, Jakarta

Badan Standarisasi Nasional. (2001). Standar Mutu Sukrosa, SNI 01-3140-2001. Dewan Standarisasi Nasional, Jakarta 
Badan Standarisasi Nasional. (1987).Standar Mutu Asam Sitrat, SNI 06-0079-1987. Dewan Standarisasi Nasional, Jakarta

Badan Standarisasi Nasional. (2008). Standar Mutu Permen Jelly, SNI 3547.2-2008. Dewan Standarisasi Nasional, Jakarta

Dinas Pertanian Tanaman Pangan Dan Hortikultura. (2013). Laporan Tahunan Dinas Pertanian Tanaman Pangan Dan Hortikultura Kabupaten Kutai Kartanegara. Tenggarong

Sudarwati S, Abadi FR, Widowati R.. (2006). Laporan Kegiatan Teknologi Pengemasan dan Pengolahan Limbah Nenas. BPTP Kalimantan Timur. Samarinda 